\title{
Numerical study of flat plate solar collector performance with square shape wicked evaporator
}

\author{
Basil N. Merzha ${ }^{a *}$, Majid H. Majeed ${ }^{b}$, and Fouad A. Saleh \\ ${ }^{a}$ Power department, Al-Furat Al-Awsat Technical University, Iraq \\ ${ }^{b}$ Middle Technical University, Iraq \\ ${ }^{c}$ Mechanical department, Mustansiriyah University, Iraq
}

\section{ARTICLE INFO}

\section{Article history:}

Received 23 May 2019

Received in revised form 18 June 2019

Accepted 25 June 2019

\section{Keywords:}

Wicked heat pipe

Flat plate

Solar collector

Radiation

\begin{abstract}
A B S T R A C T
In this work, a system of a heat pipe is implemented to improve the performance of flat plate solar collector The model is represented by square shape portion of the evaporator section of wicked heat pipe with a constant total length of $510 \mathrm{~mm}$, and the evaporator section inclined by an angle of $30^{\circ}$. In this models the evaporator, adiabatic and condenser lengths are $140 \mathrm{~mm}, 140 \mathrm{~mm}$, and $230 \mathrm{~mm}$ respectively. The omitted energies from sunlight simulator are $200,400,600,800$ and $1000 \mathrm{~W} / \mathrm{m}^{2}$ which is close to the normal solar energy in Iraq. The working fluid for all models is water with fill charge ratio of $240 \%$. The efficiency of the solar collector is investigated with three values of condenser inlet water temperatures, namely $(12,16$ and $20^{\circ} \mathrm{C}$ ). The numerical result showed an optimum volume flow rate of cooling water in condenser at which the efficiency of collector is a maximum. This optimum agree well with the ASHRAE standard volume of flow rate for conventional tasting for flat plate solar collector. When the radiation incident increases the thermal resistance of wicked heat pipe is decreases, where the heat transfer from the evaporator to condenser increases. The numerical results showed the performance of solar collector with square shape evaporator greater than other types of evaporator as a ratio $15 \%$.
\end{abstract}

\section{Introduction}

Solar energy is considered one of the best sources of energy for many advantages. It is a huge source of potential energy, which can be obtained freely. It is also one of the permanent sources of energy which is inexhaustible and reliable because of its permanence and continuity. The fossil energy sources are causing pollution to the environment by the emission of carbon dioxide, as well as the problems of global warming, which is a serious problem now and the near future. Heat pipes which are implemented still in its young stage of development and studies, more and deep investigations are required to integrate heat pipe in solar collector systems in order to improve the heat transport)

The advantages of using the wicked heat pipe [1] long life because it has no moving parts and does not need the energy to power it in addition to the ability to work in minimum temperature difference. Moreover, it does not require maintenance except cleaning plus the parts are very compact and flexible in size, very simple in design and the heat transfers in one way known (thermal diode), and small area demanded.

Some researchers have presented theoretical studies, including Kamal A.R. Ismail [2] manufactured and tested the flat plate solar collector (FPSC) with methanol as a working fluid heat pipe. The experimental results are compared with the numerical predictions and gave very good agreement. Mahmood Mustafa Mahdy [3] was studied the effect of the adiabatic region for different three lengths of evaporator indoor for different incident radiation. The results were explained the best performance at a grope without adiabatic section. E. Azad [4] was studied the effect the interconnected wick heat pipe on the solar collector. The result shown to enhance the performance of collector can be achieved by increasing the

* Corresponding author.

E-mail address: basilnoori679@gmail.com (basil N. Merzah) 
number of heat pipes. K. Sivakumar, et al [5] Designed an elliptical shape of flat plate (HP) solar collector and presented results for various flow rates and Lc/Le ratios. Majid H. Majeed, et al [6] were studied the effect of the working fluid 134a on performance of heat pipe, the results showed when used the water as a working fluid have best performance when used R134a. Taoufik Brahim , et al [7] were studied the effect of the working fluids (water and methanol) on the performance of solar collector with wicked heat pipe. The results showed good agreement between the two models, and also it was shown that the water is better than methanol where the collector instantaneous efficiency is nearly $60 \%$. All the researchers did not analyze the square shape of the evaporator section and the numerical impact on the efficiency of the solar collector.

\section{Theoretical analysis}

The simple flat plate solar collector consists of a flat plate and the heat pipe sit in this plate that sealed and evacuated pipe lined with an annular porous wicking material and a small amount of working fluid in liquid state filled the wick. The vapor of working fluid flow in center core of the pipe. The glass cover placed upon it. Fig.1. shows the principle of possible thermal loss of a typical flat plate collector. The common methods of heat loss are infrared radiation exchanges, convection heat loss and conduction through the insulations.

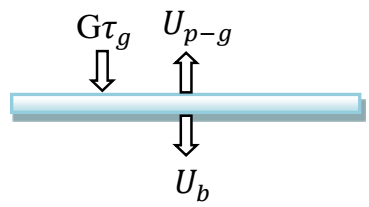

\section{Figure (1): Single-Cover typical flat plate solar collector}

For glass cover: The balance of energy $\left(\mathrm{W} / \mathrm{m}^{2}\right)$ per a unit area of the collector is denoted as shown in Fig. 2:

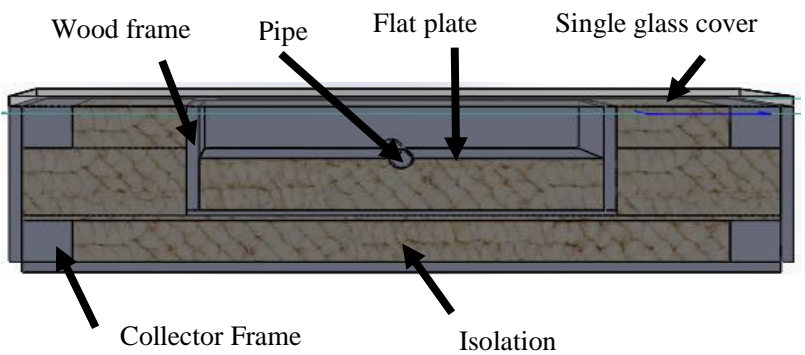

Figure (2): energy balance in the glass of solar collector

$$
\begin{aligned}
& \qquad E_{\text {inglass }}=E_{\text {out glass }} \\
& \rho_{g} \delta_{g} C_{g} \frac{d T_{g}}{d t}=\alpha_{g} G+U_{p-g}\left(T_{p}-T_{g}\right)-h_{c, g-a}\left(T_{g}-T_{a}\right)- \\
& h_{r, g-a}\left(T_{g}-T_{a}\right) \\
& \text { For steady state } \\
& \alpha_{g} G+U_{p-g}\left(T_{p}-T_{g}\right)-h_{c, g-a}\left(T_{g}-T_{a}\right)-h_{r, g-a}\left(T_{g}-T_{a}\right)=0
\end{aligned}
$$

From Duffie and Beckman

$\therefore h_{r, g-a}=\sigma \varepsilon_{g}\left(T_{g}+T_{a}\right)\left(T_{g}^{2}+T_{a}^{2}\right)$

The external radiation heat transfer coefficient between the glass and ambient depended on wind velocity $\left(v_{w}\right)$ can calculate from [8] For $0 \leq v_{w}<10$ :

$h_{c, g-a}=5.7+3.8 v_{w i}$

$U_{p-g}=\frac{1}{\frac{1}{h_{r, p-g}}+\frac{1}{h_{c, p-g}}}$

The radiation coefficient from the plate to glass is:

$h_{r, p-g}=\frac{\sigma\left(T_{p}+T_{g}\right)\left(T_{p}^{2}+T_{g}^{2}\right)}{\frac{1}{\varepsilon_{p}}+\frac{1}{\varepsilon_{g}}-1}$

Hollands et al. [9] give the equation for Nusselt number for tilt angle from $0^{\circ}$ to $75^{\circ}$.

$N u_{p-g}=1+1.44\left[1-\frac{1708(\sin 1.8 \theta)^{1.6}}{R a \cos \theta}\right]\left[1-\frac{1708}{R a \cos \theta}\right]+\left[\left(\frac{R a \cos \theta}{5830}\right)^{1 / 3}-1\right]$

For flat plate: The balance of energy $\left(\mathrm{W} / \mathrm{m}^{2}\right)$ per unit area of the collector is denoted as:

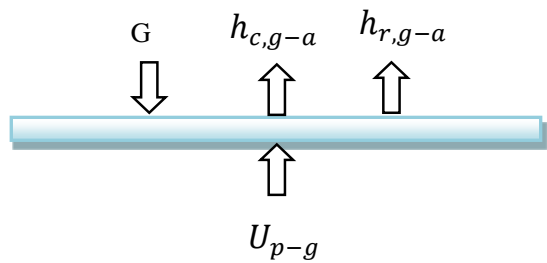

Figure (3): Energy balance in the flat plate of solar collector

$$
\begin{gathered}
\qquad E_{\text {in flat plate }}=E_{\text {out flat plate }} \\
\rho_{p} \delta_{p} C_{p} \frac{d T_{p}}{d t}=\alpha_{p} \tau_{g} G+k_{p} \delta_{p}\left(\frac{\partial^{2} T_{p}}{\partial x^{2}}\right)-U_{p-g}\left(T_{p}-T_{g}\right)- \\
U_{b}\left(T_{p}-T_{a}\right) \\
\text { For steady-state } \\
\alpha_{p} \tau_{g} G+k_{p} \delta_{p}\left(\frac{\partial^{2} T_{p}}{\partial x^{2}}\right)-U_{p-g}\left(T_{p}-T_{g}\right)-U_{b}\left(T_{p}-T_{a}\right)=0
\end{gathered}
$$

coefficient:

Duffie and Beckman can calculate the bottom heat transfer $U_{b}=\frac{K_{\text {in }}}{\delta_{\text {in }}}-$

From boundary condition as shown in Fig. 4. can be written:

$$
\begin{gathered}
\frac{d T_{p}}{d X}=0 \text { when } x=0 \\
T_{p}=T_{e} \quad \text { when } x=\frac{w}{2}
\end{gathered}
$$

For evaporator section of the wicked heat pipe the balance of energy $(\mathrm{W} / \mathrm{m})$ is denoted as:

$$
\begin{aligned}
& \rho_{e} A_{e} C_{e} \frac{d T_{e}}{d t}=\left[\tau_{g} \alpha_{p}\right]_{e} G \frac{d_{o}}{2}+k_{p} \delta_{p} \frac{\partial T_{p}}{\partial x}-\frac{\pi d_{o}}{2} U_{e g}\left(T_{e}-T_{g}\right)- \\
& \pi d_{e i} h_{e i}\left(T_{e}-T_{s}\right)-k_{e f f} L_{e} \frac{T_{e}-T_{w}}{\delta_{w}}
\end{aligned}
$$

The heat transfer coefficient of the wicked evaporator is given by B.Sivaraman [10]

$h_{e i}=\frac{3}{4}\left[\frac{\rho_{l}^{2} k^{3} g h_{f g}}{4 \mu_{l}\left(T_{e}-T_{s}\right) L_{e}}\right]^{\frac{1}{4}}$

The energy balance of the wick in the heat pipe $\left(\mathrm{w} / \mathrm{m}^{3}\right)$ is given:

$(\rho C)_{e f f}\left[\frac{\partial T}{\partial t}\right]=k_{e f f}\left[\frac{\partial^{2} T}{\partial x^{2}}\right]$ 
The effective thermal conductivity and heat capacity of wick structure, for screen wire mesh, are written as:[11, 12]

$K_{\text {eff }}=K_{l} * \frac{\left[\left(K_{l}+K_{w}\right)-\left((1-\varepsilon) *\left(K_{l}-K_{w}\right)\right)\right]}{\left[\left(K_{l}+K_{w}\right)+\left((1-\varepsilon) *\left(K_{l}-K_{w}\right)\right)\right]}$

Where;

$K_{e f f}$ : Effective thermal conductivity

$(\rho C)_{e f f}=\boldsymbol{\varepsilon}\left(\rho C_{p}\right)_{l}+(1-\varepsilon)(\rho C)_{w}$

$N u_{e-g}=1+1.44\left[1-\frac{1708(\sin 1.8 \theta)^{1.6}}{R a \cos \theta}\right]\left[1-\frac{1708}{R a \cos \theta}\right]+\left[\left(\frac{R a \cos \theta}{5830}\right)^{1 / 3}-1\right]$.

$R a_{e-g}=\frac{g \beta\left(T_{e}-T_{g}\right) x^{3}}{v \alpha}$

$h_{r, e-g}=\frac{\sigma\left(T_{e}+T_{g}\right)\left(T_{e}^{2}+T_{g}^{2}\right)}{\frac{1}{\varepsilon_{e}}+\frac{1}{\varepsilon_{g}}-1}$

The energy balance (w) for working fluid (water) will be saturated liquid because the density for vapor phase compared to liquid phase is small.

$\frac{\pi d_{i}^{2}}{4} \rho_{l} \varphi L_{t} C_{l} \frac{d T_{s}}{d t}=\pi d_{i} L_{e} h_{e}\left(T_{e}-T_{s}\right)-\pi d_{i} L_{c} h_{c}\left(T_{s}-T_{c}\right)$

For steady-state

$\pi d_{i} L_{e} h_{e}\left(T_{e}-T_{s}\right)=\pi d_{i} L_{c} h_{c}\left(T_{s}-T_{c}\right)$

In condenser section of the thermosyphon in flat plate solar collector, the heat-transfer coefficient of condensation film $\left(h_{c}\right)\left(\mathrm{W} / \mathrm{m}^{2} \mathrm{~K}\right)$ may be calculated by the relation concluded by $[\mathbf{1 3}]$ as follows:

$h_{c}=\left[0.997-0.334(\cos \theta)^{0.108}\right]\left[\frac{k_{l}^{3} \rho_{l}^{2} g h_{f g}}{\mu_{l} L_{c}\left(T_{s}-T_{c}\right)}\right]^{0.25}\left[\frac{L_{c}}{d_{i}}\right]^{\left[0.254(\cos \theta)^{0.385}\right]}$

For condenser section fig (4): The balance of energy (W/m) of the thermosyphon is represented as:

$\rho_{c} A_{c} C_{c} \frac{d T_{c}}{d t}=k_{c} A_{c} \frac{\partial^{2} T_{c}}{\partial x^{2}}+\pi d_{v} h_{c}\left(T_{s}-T_{c}\right)+K_{e f f} L_{c} \frac{T_{w}-T_{c}}{\delta_{w}}-$ $\pi d_{o} h_{c i}\left(T_{c}-T_{w}\right)$

The boundary conditions are:

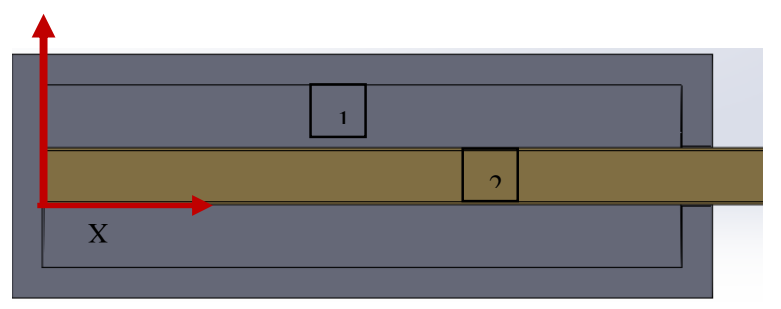

Figure (4): the coordinate of the condenser section

At $x=0 \rightarrow T_{c}=T_{S}$

At $x=L_{c} \rightarrow \frac{d T_{c}}{d x}=0$

The heat transfer coefficient of a wicked condenser is given by B.Sivaraman[10]

$h_{c i}=\frac{3}{4}\left[\frac{\rho_{l}^{2} k^{3} g h_{f g}}{4 \mu_{l}\left(T_{e}-T_{s}\right) L_{c}}\right]^{\frac{1}{4}}$

The radiation incident energy absorbed by the absorber flat plate can be classified into useful energy and to energy losses. Useful energy is the energy received from the condenser, but the lost energy has a great value that is through the top and less value by the sides, undermost and edges of the collector through the insulator. This energy loss can be calculate by heat transfer coefficient from top $\left(U_{t}\right)$ through glass, rear heat transfer coefficient $\left(\mathrm{U}_{\mathrm{b}}\right)$ through rear insulation and rim heat transfer coefficient $\left(U_{e}\right)$ through the rim insulation of the collector. Thus the overall heat coefficient from the collector are calculated from [8]

$$
U_{t o t}=U_{t}+U_{b}+U_{e}
$$

To found losses from top, Bergman, T.L give the relation[14]

$$
\begin{aligned}
& U_{t}=\frac{1}{\frac{N}{\frac{C}{T_{p m}}\left[\frac{T_{p m-T_{a}}}{N+f}\right]^{e}}+\frac{1}{h_{w i}}}+ \\
& \frac{\sigma\left(T_{p m}+T_{a}\right)\left(T_{p m}^{2}+T_{a}^{2}\right)}{\left(\varepsilon_{p}+0.0059 N h_{w i}\right)^{-1}+\frac{2 N+f-1+0.133 \varepsilon_{p}}{\varepsilon_{g}}-N} \\
& f=\left(1+0.089 h_{w}-0.1166 h_{w} \varepsilon_{p}\right)(1+0.07866 N) \\
& C=520\left(1-0.000051 \theta^{2}\right) \text { For } 0<\theta<70 \\
& e=0.430\left(1-\frac{100}{T_{p m}}\right) \\
& h_{w}=5.7+3.8 v_{w} \\
& U_{e}=\frac{(U A)_{e}}{A_{\text {coll }}} \\
& U_{e}=\frac{2 k_{\text {in }}\left(l_{\text {coll }}+w_{\text {coll }}\right) H_{\text {coll }}}{l_{\text {coll }} * w_{\text {coll }} * \delta_{\text {ine }}} \\
& \eta=
\end{aligned}
$$

$\eta=\frac{Q_{u}}{G A_{\text {coll }}}$

$\frac{Q_{u}}{A_{\text {coll }}}=G \alpha \tau \operatorname{Cos} \theta_{i}-U_{\text {tot }}\left(T_{f}-T_{a m b}\right)$

Another expression

$\eta=\frac{m C_{p}\left(T_{c o}-T_{c i}\right)}{A_{\text {coll }} G}$

Computer simulations have become important in engineering sciences because they have wide options for simulation to improve or develop designs [15] COMSOL multiphysics is one of the programs that has an integrated environment to solve differential equations of one dimension or two dimensions as well as three dimensions and it possesses sophisticated simulation tools can be easily used [15].

The 3D model of the solar flat plate collector was carried out by COMSOL software version 5.3 where the geometry was used to drawing of COMSOL geometry as shown in Fig. 5. for model No.1 and Fig. 6. model No.2.

For model No.1, the meshing using the normal size has consist of 4384091 domain elements, 359980 boundary elements, and 17576 edge elements, Mesh on selected domains consists of 3663427 elements. Minimum quality: 0.09402; average quality: 0.6663. As shown in Fig. 7. for model No.1. For model No.2, the meshing using the normal size has consist of 2737951 domain elements, 459780 boundary elements, and 27775 edge elements, Mesh on selected domains consists of 3663427 elements. Minimum quality: 0.152; average quality: 0.684., and Fig. 8. for model No. 2. 


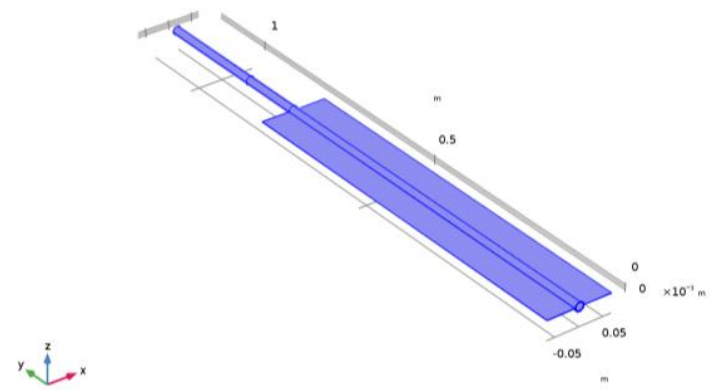

Figure (5): Geometry model No.1

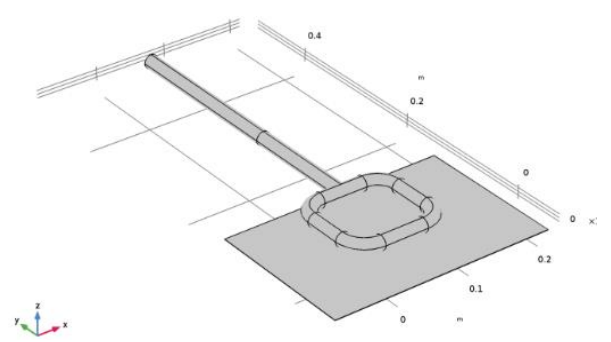

Figure (6): Geometry model No.2

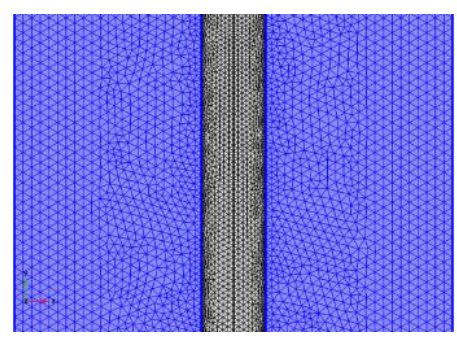

Figure (7): Mesh of the geometry model No.1 for flat plate and evaporator section

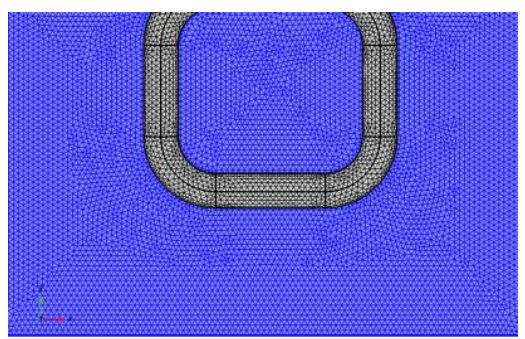

Figure (8): Mesh of the geometry model No.2 for flat plate and square shape evaporator section

In this analysis one volume fraction concentrations (240\%) [16] that effected on physical properties, with volume flow rate $(3.75,4.35$ and $101 / h)$ with various inlet temperatures was introduced and the pressure outlet condition is carried at the exit. The thermo- physical properties of the working fluid (distilled water) is variable with temperature input. Impermeable boundary and no-slip wall conditions was performed on the channel walls.

\section{Results and discussion}

The effect of energy incident variation on wicked heat pipe behaviour was represented in Fig. 9. It is noticed from the forms of the first and second models see Figs. 10-13. when the incident radiation increases the flat plate temperature and evaporator section temperature increase too and the heat pipe transport more heat to condenser section then the temperature of condenser increases some degrees. This is due to increasing of the working fluid evaporation rate with increasing of the incident radiation, which the vapor velocity increases, this is due to increasing of the mass stream rate of evaporation for water and that with increasing of the incident radiation the liquid velocity will increase.Figs. 14.-16 show the temperature contours for model that heat pipe with square shape evaporator. All these figures show the effect of variation of inlet water temperature on temperature distribution for pure water and the same incident radiation and same ambient temperature. In this figures show the models temperature contours, when the water temperature entering to the heat exchanger is increasing, the temperature off the condenser surface increases and the temperature off the flat plate and evaporator remains almost constant and will decrease the vapor velocity due to increasing the vapor density[17]. Figs. 17.-19. show the temperature contours for model that wicked heat pipe with square shape evaporator. All these figures show the effect of variation of flow rate on temperature distribution for pure water and the same incident radiation and same ambient temperature. From the observation of this figures that the temperature of the condenser section were reduced with the raise of the volume flow rate of water with a slight increase in the temperature of evaporator section and flat plate because the increase in water flow rate will increase the process of heat transfer and thus condense a larger amount of water vapor. Fig. 20. show the effect of flat plate temperature on the collector efficiency for a model that wicked heat pipe with square shape evaporator, for different ambient temperature each figure and different inlet water temperature. Fig. 21. show the effect of flat plate temperature on the collector efficiency for a model that wicked heat pipe with square shape evaporator, for different ambient temperature each figure and different inlet water temperature.

In the above figures, notice that when the plate temperature rise the collector efficiency is increasing for different ambient temperature and different inlet water temperature because the amount of water vapor is increasing and note that when the higher ambient temperature, the collector efficiency increases for this model because the heat transfer coefficient is less and thus less heat losses and thus causes increase in useful energy result that collector efficiency increases. Figs. 22-23 show the effect of the factor $\left[\left(\mathrm{T}_{\mathrm{amb}}-\mathrm{T}_{\mathrm{win}}\right) / \mathrm{G}\right]$ on the performance of solar collector $(\mathrm{SC})$ when the change stream rate of water. It could be evaluated that the performance of the collector by using a curve fitting method. The relationship represents as a first order, in figure the Intersection efficiency curve with y-axis was represented $F_{R}(\tau \alpha)$ whereas the tendency of the efficiency curve appears $F_{R} U_{L}$ hence, the performance of collector may be calculated from:

$$
\eta=F_{R}(\tau \alpha)-F_{R} U_{L}\left(\frac{T_{a m b}-T_{w i n}}{G}\right)
$$


Table 1. for the model that wicked heat pipe with square shape evaporator was summarized the values of $F_{R}(\tau \alpha)$ and $F_{\mathrm{R}} \mathrm{U}_{\mathrm{L}}$ for the various water volume stream rates

\begin{tabular}{|c|c|c|}
\hline$\dot{m}_{\text {win }}(\mathrm{kg} / \mathrm{s})$ & $F_{R}(\tau \alpha)$ & $F_{R} U_{L}$ \\
\hline 0.00104 & 0.2246 & 0.6114 \\
\hline 0.0012 & 1.5332 & 0.6573 \\
\hline 0.00278 & 2.2641 & 0.6484 \\
\hline
\end{tabular}

As shown in Fig. 22. and 1. the performance of collector is at a high value when a water volume stream rate of $4.35 \mathrm{~kg} / \mathrm{h}$. This water volume stream rate is extremely near to the ASHRAE norm for bloc stream average for examining FPS heating collectors $\dot{m}_{\text {win }}=0.0012=0.02 A[18]$
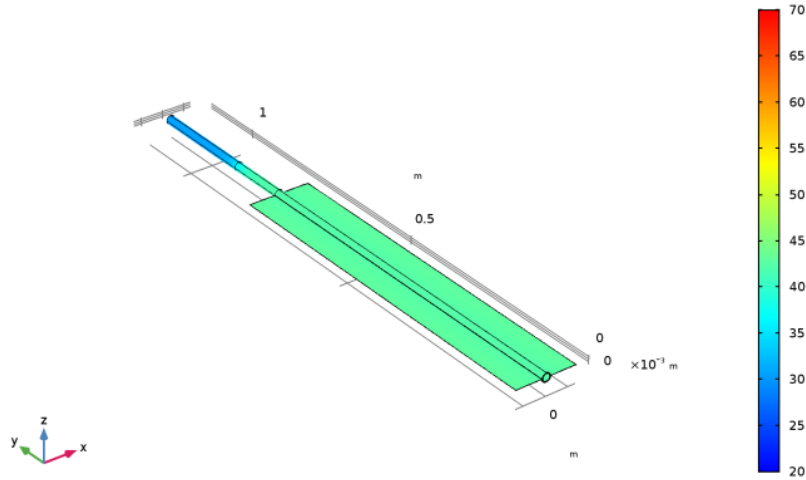

Figure (9): Temperature distribution Contour for flat plate collector with wicked heat pipe at energy input $200 \mathrm{w} / \mathrm{m}^{2}$ and inlet water temperature $12^{\circ} \mathrm{C}$ and flow rate $3.75 \mathrm{l} / \mathrm{h}\left(\right.$ area $\left.0.06 \mathrm{~m}^{2}\right)\left(\mathrm{Tamb}=27^{\circ} \mathrm{C}\right)$

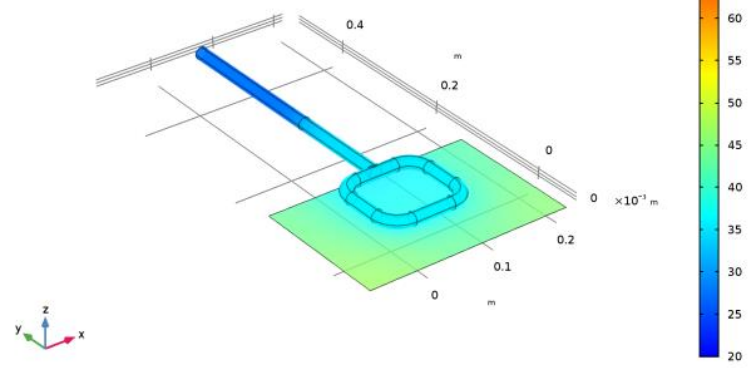

Figure (10): Temperature distribution Contour for flat plate collector with wicked heat pipe at energy input $200 \mathrm{w} / \mathrm{m}^{2}$ and inlet water temperature $12^{\circ} \mathrm{C}$ and flow rate $3.75 \mathrm{l} / \mathrm{h}\left(\right.$ area $\left.0.06 \mathrm{~m}^{2}\right)\left(\mathrm{T}_{\mathrm{amb}}=27^{\circ} \mathrm{C}\right)$

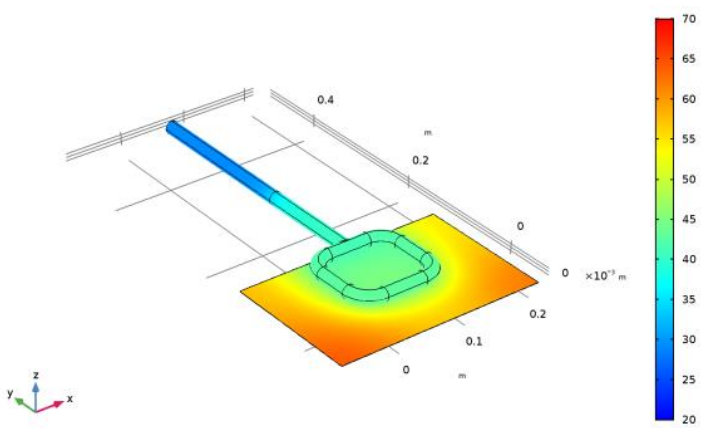

Figure (11): Temperature distribution Contour for flat plate collector with wicked heat pipe at energy input $400 \mathrm{w} / \mathrm{m}^{2}$ and inlet water temperature $12^{\circ} \mathrm{C}$ and flow rate $3.75 \mathrm{I} / \mathrm{h}\left(\right.$ area $\left.0.06 \mathrm{~m}^{2}\right)\left(\mathrm{T}_{\mathrm{amb}}=27^{\circ} \mathrm{C}\right)$

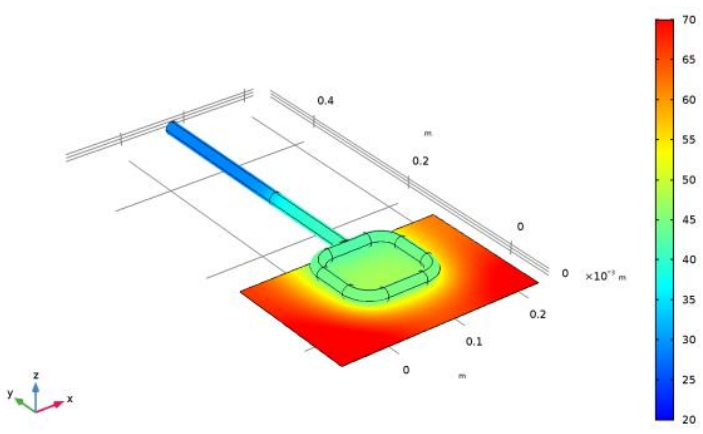

Figure (12): Temperature distribution Contour for flat plate collector with wicked heat pipe at energy input $600 \mathrm{w} / \mathrm{m}^{2}$ and inlet water temperature $12^{\circ} \mathrm{C}$ and flow rate $3.75 \mathrm{I} / \mathrm{h}$ (area $\left.0.06 \mathrm{~m}^{2}\right)\left(T_{a m b}=27^{\circ} \mathrm{C}\right)$

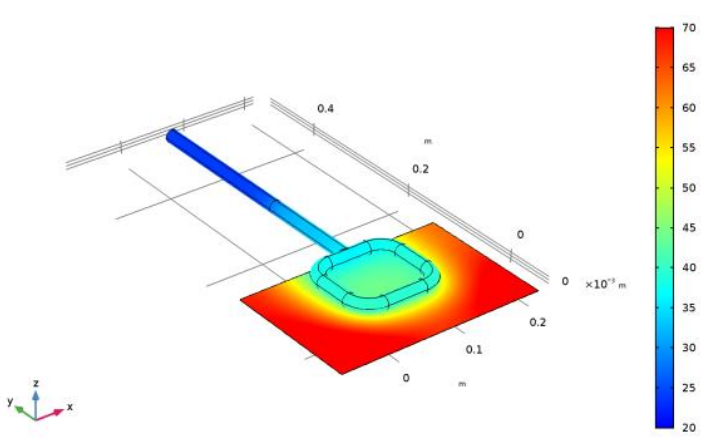

Figure (13): Temperature distribution Contour for flat plate collector with wicked heat pipe at energy input $800 \mathrm{w} / \mathrm{m}^{2}$ and inlet water temperature $12^{\circ} \mathrm{C}$ and flow rate $3.75 \mathrm{l} / \mathrm{h}\left(\right.$ area $\left.0.06 \mathrm{~m}^{2}\right)\left(T_{a m b}=27^{\circ} \mathrm{C}\right)$ 


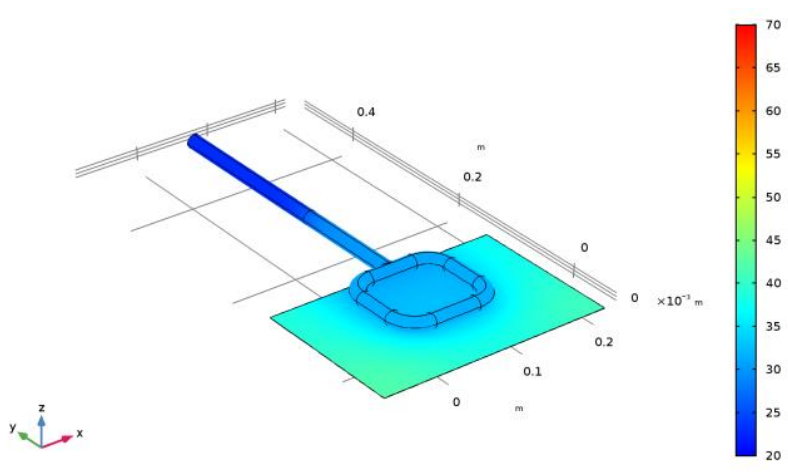

Figure (14): Temperature distribution Contour for flat plate collector with wicked heat pipe at energy input $200 \mathrm{w} / \mathrm{m}^{2}$ and inlet water temperature $12^{\circ} \mathrm{C}$ and flow rate $4.35 \mathrm{l} / \mathrm{h}$ (area $\left.0.06 \mathrm{~m}^{2}\right)\left(T_{a m b}=20^{\circ} \mathrm{C}\right.$ )

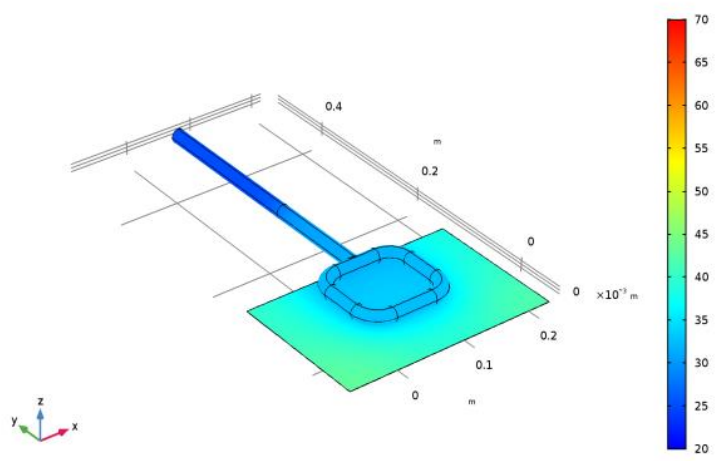

Figure (15): Temperature distribution Contour for flat plate collector with wicked heat pipe at energy input $200 \mathrm{w} / \mathrm{m}^{2}$ and inlet water temperature $16^{\circ} \mathrm{C}$ and flow rate $4.35 \mathrm{l} / \mathrm{h}\left(\right.$ area $\left.0.06 \mathrm{~m}^{2}\right)\left(\mathrm{T}_{\mathrm{amb}}=20^{\circ} \mathrm{C}\right)$

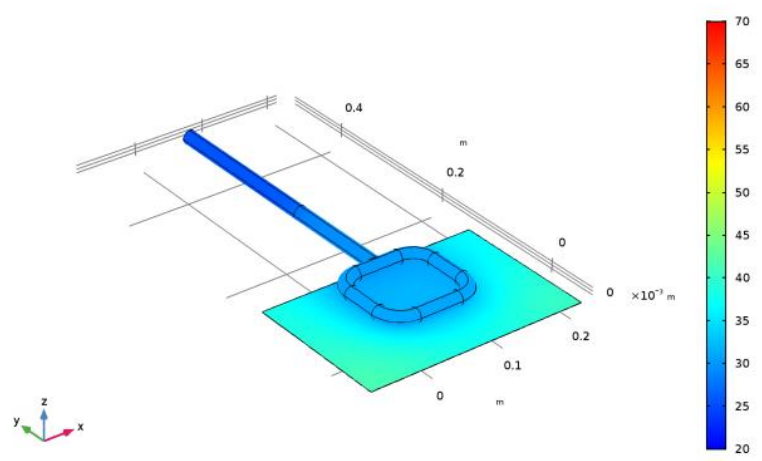

Figure (16): Temperature distribution Contour for flat plate collector with wicked heat pipe at energy input $200 \mathrm{w} / \mathrm{m}^{2}$ and inlet water temperature $20^{\circ} \mathrm{C}$ and flow rate $4.35 \mathrm{l} / \mathrm{h}$ (area $\left.0.06 \mathrm{~m}^{2}\right)\left(\mathrm{T}_{\mathrm{amb}}=20^{\circ} \mathrm{C}\right.$ )

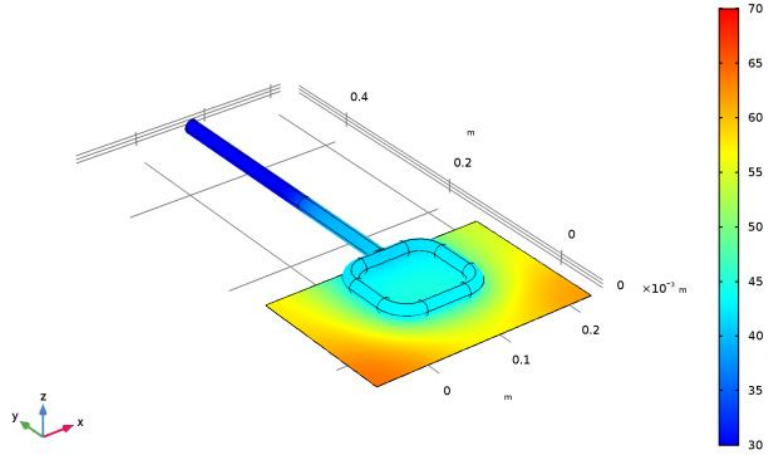

Figure (17): Temperature distribution Contour for flat plate collector with wicked heat pipe at energy input $400 \mathrm{w} / \mathrm{m}^{2}$ and inlet water temperature $12^{\circ} \mathrm{C}$ and flow rate $3.75 \mathrm{l} / \mathrm{h}$ (area $\left.0.06 \mathrm{~m}^{2}\right)\left(T_{a m b}=27^{\circ} \mathrm{C}\right)$

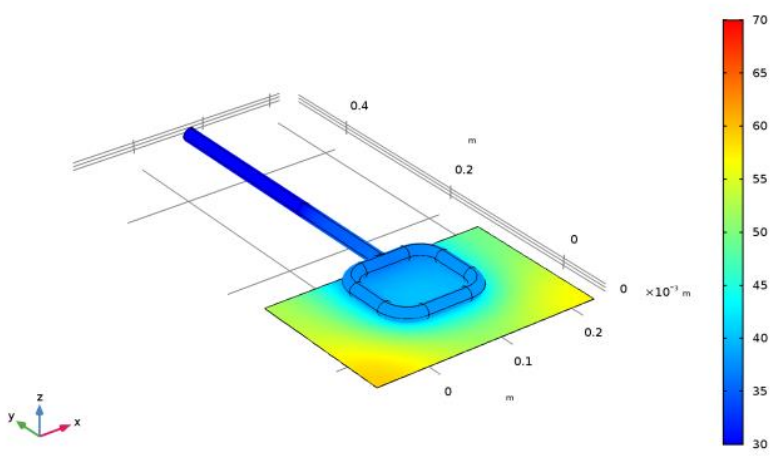

Figure (18): Temperature distribution Contour for flat plate collector with wicked heat pipe at energy input $400 \mathrm{w} / \mathrm{m}^{2}$ and inlet water temperature $12^{\circ} \mathrm{C}$ and flow rate $4.35 \mathrm{I} / \mathrm{h}$ (area $\left.0.06 \mathrm{~m}^{2}\right)\left(T_{a m b}=27^{\circ} \mathrm{C}\right.$ )

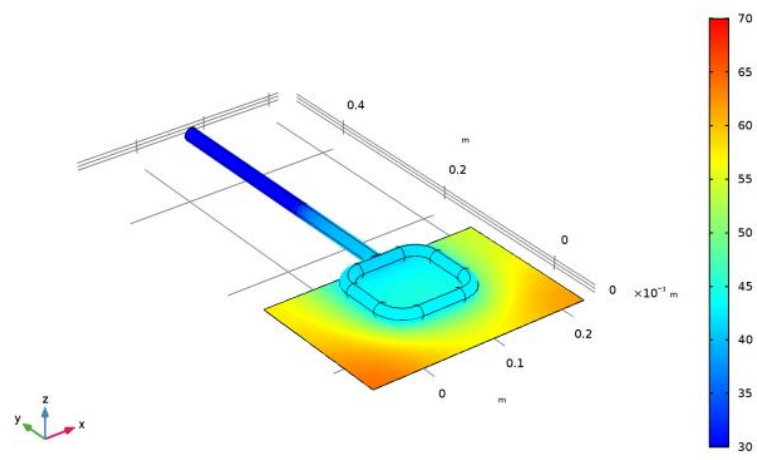

Figure (19): Temperature distribution Contour for flat plate collector with wicked heat pipe at energy input $400 \mathrm{w} / \mathrm{m}^{2}$ and inlet water temperature $12^{\circ} \mathrm{C}$ and flow rate $10 \mathrm{I} / \mathrm{h}$ (area $\left.0.06 \mathrm{~m}^{2}\right)\left(\mathrm{T}_{\mathrm{amb}}=27^{\circ} \mathrm{C}\right.$ ) 

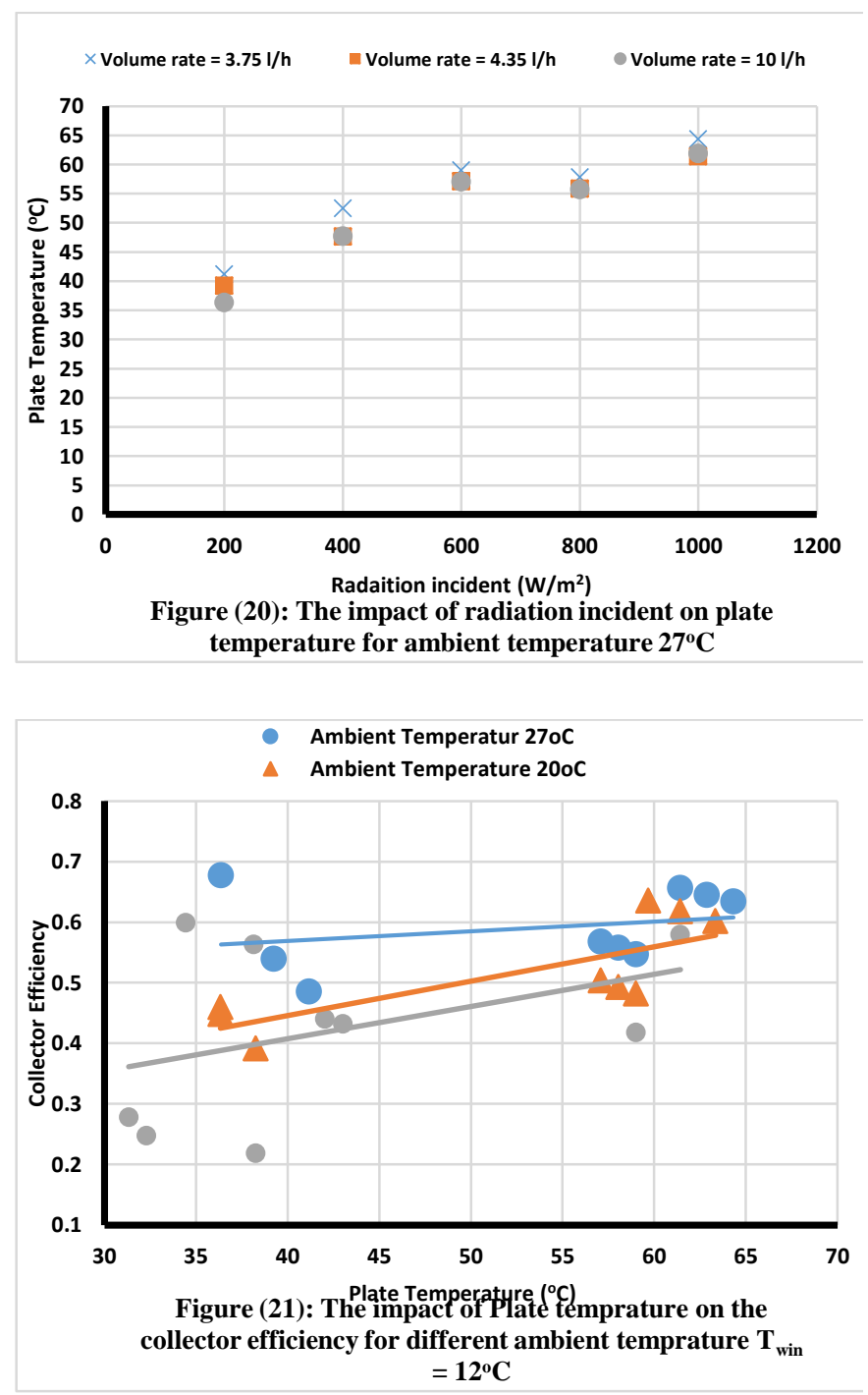

\section{Conclusion}

The flat plate solar collector with a wicked heat pipe that square shape evaporator was studied numerically. It is hoped that the information included in present study will help engineers to become more familiar with the various options available in the use of heat pipe in solar collector by for enhancing the efficiency of collector by using square shapes of evaporator. From the numerically woke the flowing can be concluded:

1- The numerical tests were demonstrated the best volume flow rate of cooling water in condenser when $\dot{m}_{\text {win }}=0.02 \mathrm{~A}$ at which the efficiency of collector is a greatest. This flow rate equal to $4.35 \mathrm{l} / \mathrm{h}$ for each numerical model. This optimum approves with the ASHRAE Standard volume flow rate for exam the conventional solar water collectors.

2- When the radiation incident increases the thermal resistance of wicked heat pipe that square shape evaporator decreases, where the heat transfer from the evaporator to condenser increases.

3- The numerical result showed the performance of solar collector with square evaporator shape greater than conventional heat pipe solar collector as a ratio (15) \%.
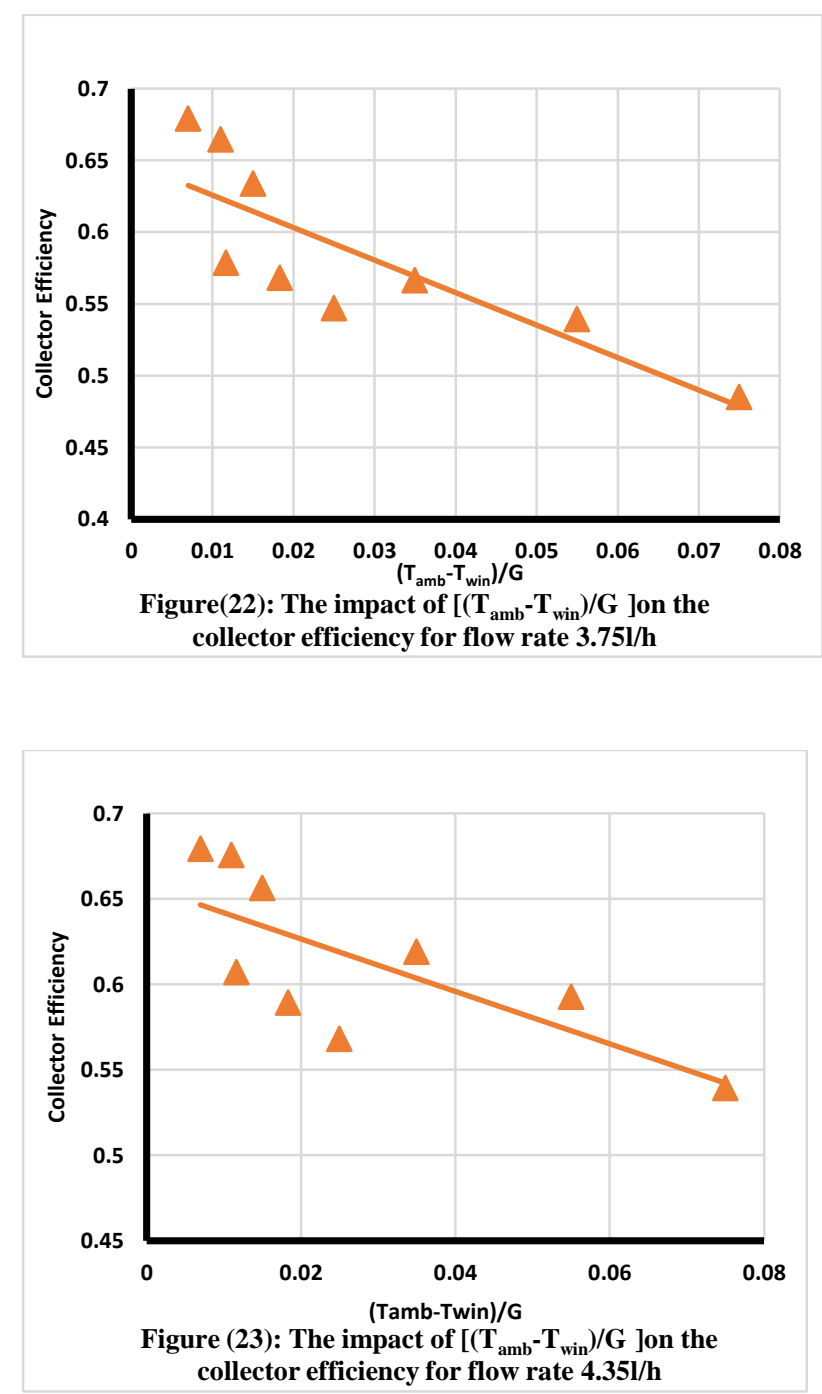

\section{REFERENCES}

[1] B. Zohuri, Heat pipe design and technology, Springer, 2011.

[2] K.A.R.I.a.M.K. Abogderah, Residential Solar Collector with Heat Pipes, in, Brazi1, 1992.

[3] M.M. Mahdy, Experimental investigation of low heat flux heat pipes with and without adiabatic suction or solar application, College of Engineering, University of Baghdad, 2005.

[4] E. Azad, Theoretical and experimental investigation of heat pipe solar collector, Experimental Thermal and Fluid Science, 32(8) (2008) 1666-1672.

[5] K. Sivakumar, N.K. Mohan, B. Sivaraman, Performance analysis of elliptical heat pipe solar collector, Indian Journal of Science and Technology, 4(1) (2011) 4-7.

[6] A.Q.M.a.B.N.A. Majid H. Majeed, Experimental Study of Heat Pipe Operating with R-134a, global journal of engineering research and technology, 3 (2013) 9. 16.

[7] T. Brahim, M.H. Dhaou, A. Jemni, Theoretical and experimental investigation of plate screen mesh heat pipe solar collector, Energy conversion and 
management, 87 (2014) 428-438.

[8] J.A. Duffie, Beckman, W. A., Solar Engineering of Thermal Processes, John Wiley \& Sons, Inc, 1991

[9] K. Hollands, T. Unny, G. Raithby, L. Konicek, Free convective heat transfer across inclined air layers, Journal of Heat Transfer, 98(2) (1976) 189-193.

[10] B. Sivaraman, N.K. Mohan, Analysis of Heat Pipe Solar Collector with different Heat Pipe Parameters, International Energy Journal, 8(2) (2007).

[11] S. Chi, Heat pipe theory and practice, Washington, DC, Hemisphere Publishing Corp.; New York, McGraw-Hill Book Co., 1976. 256 p., (1976).

[12] B. Rashidian, M. Amidpour, M.J. Nasr, Modeling the transient response of the thermosyphon heat pipes, in: Proceedings of the World Congress on Engineering, 2008, pp. 2-4.

[13] H. Hussein, Theoretical and experimental investigation of wickless heat pipes flat plate solar collector with cross flow heat exchanger, Energy Conversion and Management, 48(4) (2007) 1266-1272.

[14] T.L. Bergman, F.P. Incropera, A.S. Lavine, D.P. Dewitt, Introduction to heat transfer, John Wiley \& Sons, 2011.

[15] COMSOL, introduction to COMSOL multiphysics, in, 2017.

[16] H.G. HAMEED, NUMERICAL AND EXPERIMENTAL STUDY OF FLOW AND HEAT TRANSFER ENHANCEMENT IN A CYLINDRICAL HEAT PIPE USING NANOFLUID, UNIVERSITY OF BASRAH, 2015.

[17] O.T. Fadhil, Numerical and Experimental Study on a Heat Pipe with Porous Media Wick, University of Technology, 2006.

[18] K.F. Kreider F.J. , Solar Heating and cooling: engineering, practical Design, and Economics,, Washington DC:Washington DC, (1977). 